・论坛・ 中国国家公园试点专题

\title{
国家公园体制试点区生态产品价值实现探索
}

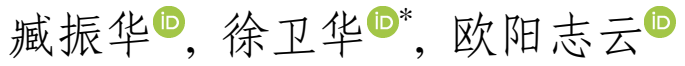

中国科学院生态环境研究中心城市与区域生态国家重点实验室, 北京 100085

藏振华，徐卫华，欧阳志云 (2021) 国家公园体制试点区生态产品价值实现探索. 生物多样性, 29, 275-277. doi: 10.17520/biods.2021084.

Zang ZH, Xu WH, Ouyang ZY (2021) Exploration on the value realization of ecological products in China's national park system pilots. Biodiversity Science, 29, 275-277. doi: 10.17520/biods.2021084.

\section{Exploration on the value realization of ecological products in China's national park system pilots}

Zhenhua Zang $^{(\mathbb{D})}$, Weihua Xu ${ }^{(\mathbb{D} *}$, Zhiyun Ouyang

State Key Laboratory of Urban and Regional Ecology, Research Center for Eco-Environmental Sciences, Chinese Academy of Sciences, Beijing 100085

自然对人类生存和良好的生活质量至关重要。 自然生态系统不仅为人类提供食品、药材、能源等 物质产品, 还提供水源涵养、气候调节、水土保持、 防风固沙等调节服务产品, 以及休闲旅游、美学体 验等文化服务产品(Ouyang et al, 2020)。但由于清洁 的空气、干净的水等生态产品大多属于公共产品, 具有外部性, 难以分清具体的权利人和受益者, 因 此难以仅依靠市场机制实现资源优化配置。生态产 品价值实现就是通过多种政策工具干预使生态产 品的价值得以真实反映, 通过已有或新建交易机制 进行交易, 解决外部性问题(高晓龙等, 2020)。建立 生态产品价值实现机制, 对于践行“绿水青山就是 金山银山”理念、推进生态文明建设具有重大意义。

国家公园是我国自然生态系统中最重要、自然 景观最独特、自然遗产最精华、生物多样性最富集 的部分, 拥有我国最宝贵的自然资源, 国民认同度 高, 开展生态产品价值实现机制探索具有得天独厚 的优势。截至目前, 我国共建立了东北虎豹、祁连 山、大熊猫等10个国家公园试点区(藏振华等, 2020), 各试点区都组建了统一的国家公园管理机构, 在实 施严格保护的同时, 也积极探索生态产品价值实现 路径, 开展“绿水青山”向“金山银山”转化的实践。

\section{推进纵向生态补偿}

国家公园全面实施天然林保护、退耕还林、森 林生态效益补偿等国家重点生态工程, 财政投资稳 步增加。试点以来, 中央层面专门安排国家公园支 出近60亿元, 试点区普遍扩大国家公园内的生态补 偿范围、提高补偿标准, 凸显国家公园的重要生态 价值。武夷山试点区对生态公益林按照每亩比区外 多3元的标准进行补偿, 对天然乔木商品林按每年 每亩20元的标准给予停伐补助, 并且从2020年开始 连续3年每年每亩增加2元; 南山试点区实施公益林 扩面工程, 将符合条件的商品林纳入公益林和天保 林管理范畴, 通过租赁实施经营权流转, 提高集体 公益林和集体天保林补偿标准, 分别由每亩每年 15.5 元和13.5元提高到30元, 截至2020年8月, 已兑 付流转补偿提标3,058户22.84万亩。

\section{2 开展横向生态补偿}

国家公园多处于大江大河源头, 或者是重要的 生态安全屏障, 部分试点省开展跨区域的横向生态 补偿试点, 体现了“谁受益、谁补偿”的公平发展原 则, 激励地方政府保护生态环境。海南省编制并执 
行《海南省流域上下游横向生态补偿实施方案(试 行)》, 以热带雨林国家公园涉及的五指山市、昌江 县、琼中县、保亭县、白沙县为试点, 签署流域上 下游横向生态保护补偿协议, 初步建立流域上下游 横向生态保护补偿机制。根据2019年流域上下游横 向生态保护补偿试点的断面水质季度考核和年度 考核结果，五指山市、琼中县、保亭县和白沙县 4 个上游市县共获得2,304万元省级奖补资金。甘肃省 2020年印发《关于加快推进祁连山地区黑河石羊河 流域上下游横向生态保护补偿试点的通知》, 祁连 山国家公园涉及的肃南县等为实施黑河流域上下 游横向生态保护补偿工作的责任主体。除签署协议 规定的补偿方式和标准外, 为激励流域所在县区开 展试点, 甘肃省财政厅和生态环境厅对符合考核相 关要求的县区予以奖励, 每个县 3 年累计奖励可达 1,000 万元。

\section{3 设立公益岗位}

国家公园增设公益岗位妥善安置当地居民和 森工企业职工, 既提高了自然资源保护效率, 又促 进当地居民增收, 维护了社会稳定。三江源试点区 整合草地管护员、护林员、湿地管护员及扶贫专项 资金，建立生态管护公益岗位机制，将管护标准从 原来的每 5 万亩设置 1 名管护员提高到每 3 万亩设置 1 名管护员，每名管护员月工资从 1,500 元提高到 1,800 元, 按照 “一户一岗” 落实生态管护员岗位 17,211个。大熊猫试点区各级管理机构共设置公益 岗位13,278 个, 其中生态管护岗位 10,777 个、社会服 务岗位 2,501 个, 原住民参与数量 11,990 人, 占比达 到 $90.3 \%$, 生态管护公益岗位工资支出达 7.38 亿元, 每人年均获得工资性收入 18,555 元。

\section{4 非国有自然资源统一管理}

集体林地占比高的国家公园试点区采取赎买、 租赁、签订保护协议等方式, 通过合理补偿, 既保 障林农利益, 又推动了国家公园管理局对非国有自 然资源的统一管理, 缓解了社区发展与生态保护之 间的矛盾(秦天宝，2019)。钱江源-百山祖试点区的 集体土地占比超过 $80 \%$, 为实现对自然资源资产的 集中统一管理, 两园区创新推进了地役权改革。在 不改变森林、林木、林地权属的基础上, 先由农户 或村民小组自行委托村民委员会管理, 再由村民代
表大会集体表决形成决议, 将管理权统一授予钱江 源国家公园管理局, 明确约定权利义务, 通过一定 的经济生态补偿限制权属所有者的行为(王宇飞等, 2019)。集体林地地役权生态补偿标准为每亩每年 48.2元, 纳入省财政预算, 随省公益林生态补偿金 的增长同步增长。通过实施地役权改革, 试点区内 集体土地几乎全部实现统一管理, 居民年均增收 400 元以上。百山祖园区在推进地役权改革的同时, 创新林地地役权补偿收益权质押贷款机制, 集体林 地的权利人可以将地役权补偿收益作为质押担保 向农商银行贷款, 贷款额度最高可达年度林地地役 权补偿收益的 20 倍, 期限最长为5年。2020年8月, 首批符合条件的10名村民代表分别获得了 20-30万 元不等的贷款授信金额，授信金额共计 250 万元。

\section{发展生态旅游}

国家公园采取特许经营方式发展生态旅游, 用 极小面积的非资源消耗型发展换取了大面积的保 护。普达措国家公园管理机构通过签订生态补偿协 议, 对集体土地实行统一管理。国家公园管理机构 将景区运营特许给国有独资企业普达措旅业分公 司, 旅游公司利用资源为游客提供游秘体验获得收 益, 每年从收益中拿出 1,690 余万元资金对 3,696 名 社区居民实施直接经济补偿。此外, 国家公园管理 机构将经营推位特许给当地居民开展土特产售卖 等经营服务活动, 当地居民还可通过资源入股形式 获得分红, 通过参与巡护、环卫、交通、解说、项 目建设等服务获得劳动报酬。武夷山试点区创新景 观资源有偿利用机制，国家公园管理局与主景区7 万余亩集体山林所有者协商, 按照景区门票收入及 商定的基数向林地所有者支付报酬。试点以来平均 每年支付 319 万元, 既解决生态游㮩发展瓶颈, 又 保障村民利益, 实现生态成果与旅游收益共享。

\section{打造优质品牌}

国家公园依托生态环境优势, 打造优质品牌, 吸引对生态产品敏感的消费者和企业, 获得溢价收 益。东北虎豹试点区大力发展绿色循环经济, 推动 产业转型, 东宁市鼓励发展黑木耳、山野菜种植等 原生态林产品产业, 利用龙头企业吸纳原有森工企 业职工及贫困户，先后创建“绥阳耳” “双枒子”等多 个著名商标, 生态优势转化成了经济优势。大熊猫 
试点区四川片区与世界自然基金会(WWF)合作，由 WWF发布 “大熊猫友好型认证标准”, 符合相关要 求的农产品将获得认证。产自平武县的中草药南五 味子(Schisandra sphenanthera)成为全球首个通过该 标准认证的产品, 已销往美国, 带动当地居民增 收。此外, 在大熊猫国家公园内和入口社区开展“蚂 蚁森林” 公益保护地试点, 借助支付宝移动互联网 平台, 推出“关坝”和“福寿”2个公益保护地, 引导社 会公众在手机支付宝中认领保护地, 获得的社会资 金用于支持生态保护与绿色发展。武夷山试点区出 台农药化肥使用管理规定, 严厉打击毁林种茶等破 坏行为, 鼓励和引导茶企、茶农按标准建设生态茶 园, 指导开展地理标志申报和绿色认证, 通过市场 营销, 武夷岩茶和正山小种等已形成良好的品牌效 应, 产生了可观的经济价值。武夷山试点区周边的 “朱喜故里”五夫镇, 利用“双世遗”品牌, 创新“文化 生态银行” 模式, 将闲散的山、水、林、田、民居等 资源整合成资产包向市场招商，成功推出了一系列 生态文旅项目，实现村集体和企业双赢。

总体而言，国家公园体制试点牢固树立人与自 然和谐共生的思想意识, 积极探索生态产品价值实 现路径, 为建立生态产品价值实现机制积累了有益 经验。但是, 目前国家公园的生态产品价值实现的 资金来源中, 政府付费占绝对主体, 公众付费、公 益组织付费的案例较少、占比很低。国家公园内的 自然资源有偿使用制度还不完善, 特许经营还不规 范，生态产品的市场和交易体系还不健全，企业参 与程度低, 公民自然保护教育还处于初级阶段, 影 响了生态产品价值实现。未来, 国家层面应继续完 善国家公园等自然保护地的政策制度体系, 为企业 等社会资本参与国家公园内及其周边产业的发展 指明方向。国家公园管理机构和相关地方政府需进 一步健全协调机制，吸引多方资金和技术支持，完 善生态产品价值核算体系, 优化市场配置, 加强监 管与引导, 将宝贵的自然资源转化为市场竞争力, 促进生态产品价值实现(高晓龙等, 2019)。只有充分 调动国家公园所在的地方政府、社区居民、企业等 多方积极性, 确保利益相关方在保护生态环境、提 供生态产品的同时不吃亏、有收益, 在破坏生态环 境、消费生态产品的同时要赔偿、需付费, 才能真 正可持续地实现国家公园的生态产品价值。
致谢：感谢国家公园管理局办公室和各国家公园体 制试点区提供支持; 本文部分资料来源于各试点区 的评估验收报告，向报告编写人员致谢。

\section{ORCID}

藏振华 (iD) https://orcid.org/0000-0002-6643-9468 徐卫华 (D) https://orcid.org/0000-0001-7622-7365 欧阳志云 (D) https://orcid.org/0000-0003-0927-0499

\section{参考文献}

Gao XL, Cheng HQ, Zheng H, Ouyang ZY (2019) Research on the policy instruments for the value realization of ecological products. Acta Ecologica Sinica, 39, 8746-8754. (in Chinese with English abstract) [高晓龙, 程会强, 郑华, 欧 阳志云 (2019) 生态产品价值实现的政策工具探究. 生 态学报, 39, 8746-8754.]

Gao XL, Lin YQ, Xu WH, Ouyang ZY (2020) Research progress on the value realization of ecological products. Acta Ecologica Sinica, 40, 24-33. (in Chinese with English abstract) [高晓龙，林亦晴，徐卫华，欧阳志云 (2020) 生 态产品价值实现研究进展. 生态学报, 40, 24-33.]

Ouyang ZY, Song CS, Zheng H, Polasky S, Xiao Y, Bateman IJ, Liu JG, Ruckelshaus M, Shi FQ, Xiao Y, Xu WH, Zou ZY, Daily GC (2020) Using gross ecosystem product (GEP) to value nature in decision making. Proceedings of the National Academy of Sciences, USA, 117, 14593-14601.

Qin TB (2019) The realization of state-owned land as dominating land in National Park: A perspective of easement. Modern Law Science, 41(3), 55-68. (in Chinese with English abstract) [秦天宝 (2019) 论国家公园国有土 地占主体地位的实现路径一一以地役权为核心的考察. 现代法学, 41(3), 55-68.]

Wang YF, Su HQ, Zhao XR, Su Y, Luo M (2019) Conservation easement-inspired adaptive management methods for natural protected areas: A case study on Qianjiangyuan National Park pilot. Biodiversity Science, 27, 88-96. (in Chinese with English abstract) [王宇飞, 苏红巧, 赵金荃芯，苏杨，罗敏 (2019) 基于保护地役权的自然保护 地适应性管理方法探讨：以钱江源国家公园体制试点区 为例. 生物多样性, 27, 88-96.]

Zang ZH, Zhang D, Wang N, Du A, Kong LQ, Xu WH, Ouyang ZY (2020) Experiences, achievement, problems and recommendations of the first batch of China's National Park system pilots. Acta Ecologica Sinica, 40, 8839-8850. (in Chinese with English abstract) [㶓振华, 张多, 王楠, 杜傲, 孔令桥, 徐卫华, 欧阳志云 (2020) 中国首批国家公园体 制试点的经验与成效、问题与建议. 生态学报, 40, 8839-8850.]

(责任编委: 马克平 责任编辑: 周玉荣) 